\title{
Studi tentang kinerja guru dan mutu hasil belajar siswa smk swasta di Kota Bandung (studi pada SMK Merdeka, SMK Pasundan 3, dan SMK Bina Sarana Cendikia)
}

\section{Study on teacher peformance and quality of learning outcome at vocational school in bandung (study at SMK Merdeka, SMK Pasundan 3, dan SMK Bina Sarana Cendikia)}

\author{
Satria Dharma Putra', Sambas Ali Muhidin ${ }^{2 *}$ \\ 1,2Program Studi Pendidikan Manajemen Perkantoran, \\ Fakultas Pendidikan Ekonomi dan Bisnis, Universitas Pendidikan Indonesia \\ Jl. Dr. Setiabudhi, No. 229 Bandung, Jawa Barat Indonesia \\ Email: sambas@upi.edu
}

\begin{abstract}
ABSTRAK
Penelitian ini bertujuan untuk menganalisis hubungan kinerja guru dan mutu hasil belajar siswa. Metode penelitian menggunakan metode survey. Teknik pengumpulan data menggunakan angket model likert. Responden adalah 20 Guru Bisnis Manajemen di Sekolah Menengah Kejuruan Swasta di Kota Bandung. Teknik analisis data menggunakan Rank Spearman. Hasil penelitian menunjukkan kinerja guru dan mutu hasil belajar memiliki hubungan yang positif dan signifikan. Dengan demikian kinerja guru berhubungan terhadap mutu hasil belajar.
\end{abstract}

Kata Kunci: Kinerja Guru; Mutu Hasil Belajar

\begin{abstract}
ABSTRAK
This study aims to analyze the relationship between teacher performance and the quality of student learning outcomes. The research method used survey method. Technique of collecting data using questioner of likert model. Respondents are 20 Management Business Teachers at Private Vocational High School in Bandung City. Data analysis technique using Rank Spearman. The results showed that teacher performance and quality of learning outcomes have a positive and significant relationship. Thus the performance of teachers relates to the quality of learning outcomes.
\end{abstract}

Keywords: Teacher Performance; Quality of Student Learning

\section{PENDAHULUAN}

Pendidikan memilik peranan penting dalam menciptakan dan meningkatkan kualitas sumber daya manusia (SDM). Saat ini, Indonesia masih memiliki mutu pendidikan yang relatif rendah. Menurut Suryati Sidharto Permasalahan yang dihadapi

Received: Februari 2019, Revision: Mei 2019, Published: Juli 2019 
bangsa Indonesia mencakup lima pokok masalah, yaitu: Pemerataan Pendidikan, Daya Tampung Pendidikan, Relevansi Pendidikan, Kualitas/Mutu Pendidikan dan Efisiensi \& Efektifitas Pendidikan (Arif Rohman, 2009). Rendahnya mutu pendidikan di Indonesia disebabkan oleh banyak faktor, baik faktor eksternal maupun faktor internal.

Seperti Studi yang dilakukan Heyneman \& Loxley pada tahun 1983 di 29 negara menemukan bahwa diantara berbagai masukan (input) yang menentukan mutu pendidikan (yang ditunjukkan oleh prestasi belajar siswa) sepertiganya ditentukan oleh guru. Lengkapnya penelitian itu (dalam Dedi Supriadi, 1999) menyatakan di 16 negara sedang berkembang, guru memberi kontribusi terhadap prestasi belajar sebesar 34\%, sedangkan manajemen 22\%, waktu belajar 18\%, dan sarana fisik 26\%. Di 13 Negara industry, kontribusi guru adalah $36 \%$, manajemen $23 \%$, waktu belajar $22 \%$, dan sarana fisik $19 \%$. Hasil dari penelitian di atas menunjukkan bahwa kontribusi guru sebesar $36 \%$, yang menunjukkan bahwa guru lebih dominan menunjang mutu pendidikan(mutu hasil belajar) peserta didik.

Guru memiliki peranan penting dalam menunjang mutu pendidikan yang dilihat melalui kinerja guru. Kinerja guru yang kompeten akan menghasilkan siswa yang kompeten. Siswa Sekolah Menengah Kejuruan (SMK) di tuntut untuk kompeten dalam bidang tertentu dan siap bekerja. Namun kenyataanya, siswa lulusan SMK di kota Bandung memiliki tingkat pengangguran yang meningkat setiap tahunya.

Tabel 1.

Tingkat Pengangguran Terbuka (TPT) Lulusan SMK di Kota Bandung

\begin{tabular}{|c|l|c|c|c|}
\hline Tahun & Bekerja & Pengangguran & Total & $\begin{array}{c}\text { Tingkat Pengangguran } \\
\text { Terbuka (TPT) }\end{array}$ \\
\hline 2014 & $\begin{array}{c}1.961 .884 \\
(10,09 \%)\end{array}$ & $\begin{array}{c}223.441 \\
(12,12 \%)\end{array}$ & $\begin{array}{c}2.185 .325 \\
(10,27 \%)\end{array}$ & $10,22 \%$ \\
\hline 2015 & $\begin{array}{c}2.102 .668 \\
(10,28 \%)\end{array}$ & $\begin{array}{c}227.881 \\
(14,81 \%)\end{array}$ & $\begin{array}{c}2.380 .549 \\
(10,66 \%)\end{array}$ & $11,67 \%$ \\
\hline 2016 & $\begin{array}{c}2.310 .215 \\
(11,39 \%)\end{array}$ & $\begin{array}{c}385.419 \\
(20,29 \%)\end{array}$ & $\begin{array}{c}2.695 .634 \\
(12,16 \%)\end{array}$ & $14,30 \%$ \\
\hline
\end{tabular}

Sumber: BPS

Dari data di atas, dapat dilihat bahwa dari tahun 2014 terdapat 12,12\% pengangguran lulusan SMK kemudian di tahun 2015 terjadi peningkatan pengangguran lulusan SMK sebesar $2.69 \%$ yaitu 14.81\%. Di tahun 2016 terjadi peningkatan yang lumayan tinggi yaitu sebesar $5.48 \%$ sehingga menjadi $20.29 \%$. Hal ini mengambarkan bahwa masih rendahnya keterserapan lulusan kota bandung. Menurut Direktur Statistik Kependudukan dan Ketenagakerjaan Badan Pusat Statistik (DSKK BPS), Razali Ritonga(2016) Lulusan sekolah menengah kejuruan (SMK) paling banyak yang menganggur karena kesulitan mencari pekerjaan yang sesuai dengan keahliannya. Selain itu salah satu faktor lain yang menyebabkan sulitnya lulusan SMK bersaing adalah karena kurangnya kemampuan kognitif yang dinilai dari hasil ujian. Sama halnya Kepala Dinas Pendidikan DKI Jakarta Larso Marbun (2014) menilai Kompetensi yang masih rendah menjadi alasan bertambahnya pengangguran lulusan dari sekolah menengah kejuruan (SMK). Hal ini menunjukkan bahwa tingginya pengangguran lulusan SMK karena kemampuan kognitif lulusan SMK yang rendah. Rendahnya kemampuan kognitif lulusan SMK karena rendahnya kinerja guru di Sekolah Menengah Kejuruan (SMK). Kondisi seperti ini tentu tidak boleh dibiarkan terus terjadi, karena 
terus meningkatnya pengangguran lulusan SMK bisa memberikan dampak buru terhadap citra Lulusan SMK siap kerja.

Berdasarkan hal tersebut rumusan masalah dari penelitian ini adalah "seberapa kuatkah hubungan kinerja guru dengan mutu hasil belajar siswa?". Dengan demikian tujuan penelitian ini adalah untuk menganalisis hubungan kinerja guru dengan mutu hasil belajar siswa.

\section{TINJAUAN PUSTAKA \\ Kinerja Guru}

Secara umum, kinerja di artikan sebagai hasil kerja yang telah dicapai seseorang pada periode tertentu(Bernardin,2016). Sedangkan menurut (A.A Anwar Prabu Mangkunegara, 2000) kinerja adalah prestasi kerja atau hasil kerja (output) baik kualitas maupun kuantitas yang dicapai sumber daya manusia persatuan periode waktu dalam melaksanakan tugas kerjanya sesuai dengan tanggungjawab yang diberikan kepadanya.

Dijelaskan pula bahwa kinerja guru adalah melaksanakan proses pembelajaran baik dilakukan di dalam kelas maupun di luar kelas di samping mengerjakan kegiatankegiatan lainnya, seperti mengerjakan administrasi sekolah dan administrasi pembelajaran, melaksanakan bimbingan dan layanan pada para siswa, serta melaksanakan penilaian(A. Tabrani Rusyan dkk, 2000)

Indikator kinerja guru (Permendiknas No.16, 2007): (1) Mengenal karaktersitik peserta didik. (2) Menguasai teori belajar dan prinsip - prinsip pembelajaran yang mendidik. (3) Pengembangan kurikulum. (4) Kegiatan pembelajaran yang mendidik. (5) Memahami dan mengembangkan potensi. (6) Komunikasi dengan peserta didik. (7) Penilaian dan evaluasi. (8) Bertindak sesuai dengan norma agama, hokum, sosial dan kebudayaan nasional Indonesia. (9) Menunjukkan pribadi yang dewasa dan teladan. (10) Etos kerja, tanggungjawab yang tinggi, rasa bangga menjadi guru. (11) Bersikap inklusif, bertindak obyektif, serta tidak diskriminatif. (12) Komunikasi dengan sesame guru, tenaga pendidik, orang tua peserta didik, dan masyarakat. (13) Penguasaan materi struktur konsep dan pola pikir keilmuan yang mendukung mata pelajaran yang diampu. (14) Mengembangkan keprofesian melalui tindakan reflektif.

\section{Mutu Hasil Belajar}

Hasil belajar di dapat melalui kegiatan pembelajaran atau proses pembelajaran yang mana diperankan oleh guru, siswa dan kurikulum dalam ruang kelas. Guru merumuskan tujuan Instruksional Khusus, yang didasarkan pada Taksonomi Blom tentang tujuan-tujuan perilaku (Bloom, 1956) yang meliputi tiga domain: kognitif, afektif, dan psikomotorik. Gagne mengemukakan tiga macam hasil belajar, tiga di antaranya berisfat kognitif, satu bersifat afektif, dan satu lagi bersifat psikomotorik. Inti dari pembelajaran itu didapatkan oleh peserta didik adalah hasil belajar

Menurut Bloom Pengembangan dari ketiga ranah tersebut dijelaskan sebagai berikut (Bloom, 1956):

1. Ranah Nilai atau Sikap (Ranah Afektif); Ranah afektif adalah ranah yang berkaitan dengan sikap dan nilai. Ranah afektif mencakup watak perilaku seperti perasaan, minat, sikap, emosi, dan nilai. Beberapa pakar mengatakan bahwa sikap seseorang dapat diramalkan perubahannya bila seseorang telah memiliki kekuasaan kognitif tingkat tinggi. Ciri-ciri hasil belajar afektif akan tampak pada peserta didik dalam berbagai tingkah laku. Seperti: perhatiannnya terhadap mata pelajaran pendidikan agama Islam, 
kedisiplinannya dalam mengikuti mata pelajaran agama disekolah, motivasinya yang tinggi untuk tahu lebih banyak mengenai pelajaran agama Islam yang di terimanya, penghargaan atau rasa hormatnya terhadap guru pendidikan agama Islam dan sebagainya. Penelitian ini menggunakan Ranah Afektif yang terdiri dari : Keimanan dan ketakwaan peserta didik kepada Tuhan YME; Karekter,Kejujuran, dan kepedulian peserta didik; Tanggungjawab peserta didik; Sifat pembelajar pada peserta didik; Kesehatan (jasmani dan rohani) peserta didik, yang sesuai dengan perkembangan anak.

2. Ranah Proses Berpikir (Ranah Kognitif); Ranah kognitif adalah ranah yang mencakup kegiatan mental (otak). Menurut Bloom, segala upaya yang menyangkut aktivitas otak adalah termasuk dalam ranah kognitif. Ranah kognitif berhubungan dengan kemampuan berfikir, termasuk didalamnya kemampuan menghafal, memahami, mengaplikasi, menganalisis, mensintesis, dan kemampuan mengevaluasi. Dalam ranah kognitif itu terdapat enam aspek atau jenjang proses berfikir, mulai dari jenjang terendah sampai dengan jenjang yang paling tinggi. Penelitian ini menggunakan Ranah Kognitif yang terdiri dari: Pengetahuan factual peserta didik berkenaan dengan ilmu pegetahuan dan teknologi yang dipelajarinya(Pengetahuan factual adalah pengetahuan yang berkaitan dengan kenyataan/empiris); Pengetahuan konseptual peserta didik berkenaan dengan ilmu pengetahuan dan teknologi yang dipelajarinya(Pengetahuan konseptual adalah pengetahuan yang berkaitan dengan konsep); Pengetahuan procedural peserta didik berkenaan dengan ilmu pengetahuan dan teknologi yang dipelajarinya(Pengetahuan procedural adalah pengetahuan yang berkaitan dengan bagaimana melakukan sesuatu); Pengetahuan metakognitif peserta didik berkenaan dengan ilmu pengetahuan dan teknologi yang diperlajarinya(Pengetahuan metakognitif adalah pengetahuan yang berkaitan dengan kesadaran tentang kemampuan berpikirnya sendiri serta mampu untuk mengaturnya).

3. Ranah Ketrampilan (Ranah Psikomotor); Ranah psikomotor merupakan ranah yang berkaitan dengan keterampilan (skill) tau kemampuan bertindak setelah seseorang menerima pengalaman belajar tertentu. Ranah psikomotor adalah ranah yang berhubungan dengan aktivitas fisik, misalnya lari, melompat, melukis, menari, memukul, dan sebagainya. Hasil belajar ranah psikomotor dikemukakan oleh Simpson (1956) yang menyatakan bahwa hasil belajar psikomotor ini tampak dalam bentuk keterampilan (skill) dan kemampuan bertindak individu. Hasil belajar psikomotor ini sebenarnya merupakan kelanjutan dari hasil belajar kognitif (memahami sesuatu) dan dan hasil belajar afektif (yang baru tampak dalam bentuk kecenderungankecenderungan berperilaku). Penelitian ini menggunakan Ranah Psikomotor yang terdiri dari: Ketrampilan berpikir dan bertindak yang kreatif dari peserta didik; Ketrampilan berpikir dan bertindak yang produktif dari peserta didik; Ketrampilan berpikir dan bertindak yang kritis dari peserta didik; Ketrampilan berpikir dan bertindak secara mandiri dari peserta didik; Ketrampilan berpikir dan bertindak secara kolaboratif dari peserta didik; Ketrampilan berpikir dan bertindak yang komunikatif dari peserta didik. 


\section{METODE PENELITIAN}

Penelitian ini menggunakan metode survey. Penelitian Survey adalah penelitian yang dilakukan terhadap sejumlah individu atau unit analisis, sehingga ditemukan fakta atau keterangan secara faktual mengenai gejala suatu kelompok atau perilaku individu, dan hasilnya dapat digunakan sebagai bahan pembuatan acara atau pengambilan keputusan(Uep dan Sambas, 2011). Responden adalah guru Sekolah Menengah Kejuruan Swasta di Kota Bandung, Provinsi Jawa Barat, Indonesia sebanyak 20 orang.

Instrumen pengumpulan data berupa angket model likert yang terdiri atas 2 bagian. Bagian pertama adalah kuesioner untuk mengukur persepsi responden mengenai kinerja guru yang dijabarkan melalui 14 indikator yaitu Mengenal karaktersitik peserta didik, Menguasai teori belajar dan prinsip - prinsip pembelajaran yang mendidik, Pengembangan kurikulum, Kegiatan pembelajaran yang mendidik, Memahami dan mengembangkan potensi, Komunikasi dengan peserta didik, Penilaian dan evaluasi, Bertindak sesuai dengan norma agama, hokum, sosial dan kebudayaan nasional Indonesia, Menunjukkan pribadi yang dewasa dan teladan, Etos kerja, tanggungjawab yang tinggi, rasa bangga menjadi guru, Bersikap inklusif, bertindak obyektif, serta tidak diskriminatif, Komunikasi dengan sesame guru, tenaga pendidik, orang tua peserta didik, dan masyarakat, Penguasaan materi struktur konsep dan pola pikir keilmuan yang mendukung mata pelajaran yang diampu, Mengembangkan keprofesian melalui tindakan reflektif. Bagian ini terdiri dari 65 item. Bagian kedua adalah kuesioner untuk mengukur persepsi responden mengenai mutu hasil belajar siswa yang dijabarkan dari tiga indikator yaitu afektif, kognitif, dan psikomotor. Bagian ini terdiri dari 15 item.

Teknik analisis data menggunakan teknik analisis data inferensial dan teknik analisis data deskriptif. Teknik analisis data inferensial adalah data dengan statistik, yang digunakan dengan tujuan untuk membuat kesimpulan yang berlaku umum. Dalam praktik penelitian, analisis statistika inferensial biasanya dilakukan dalam bentuk pengujian hipotesis. Statistika inferensial berfungsi untuk menggeneralisasikan hasil penelitian sampel bagi populasi(Uep dan Sambas, 2011). Statistik inferensial menggunakan analisis rank spearman yang digunakan untuk menguji hipotesis. Sedangkan Teknik analisis data deskriptif adalah statistic yang digunakan untuk menganalisis data dengan cara mendeskripsikan atau menggambarkan data yang telah terkumpul sebagaimana adanya tanpa bermaksud membuat generalisasi hasil penelitian (Uep dan Sambas, 2011). Statistik deskriptif menggunakan persentase untuk memperoleh gambaran tingkat persepsi responden mengenai kinerja guru, mutu hasil belajar siswa.

\section{HASIL PENELITIAN DAN PEMBAHASAN Kinerja Guru}

Instrumen yang dikembangkan pada variabel kinerja guru, dibentuk oleh indikator Mengenal karaktersitik peserta didik, Menguasai teori belajar dan prinsip prinsip pembelajaran yang mendidik, Pengembangan kurikulum, Kegiatan pembelajaran yang mendidik, Memahami dan mengembangkan potensi, Komunikasi dengan peserta didik, Penilaian dan evaluasi, Bertindak sesuai dengan norma agama, hokum, sosial dan kebudayaan nasional Indonesia, Menunjukkan pribadi yang dewasa dan teladan, Etos kerja, tanggungjawab yang tinggi, rasa bangga menjadi guru, Bersikap inklusif, bertindak obyektif, serta tidak diskriminatif, Komunikasi dengan sesame guru, tenaga pendidik, orang tua peserta didik, dan masyarakat, Penguasaan materi struktur konsep dan pola pikir keilmuan yang mendukung mata pelajaran yang diampu, 
Mengembangkan keprofesian melalui tindakan reflektif. Semua indikator tersebut diarahkan untuk mengukur bagaimanakah hubungan kinerja guru dengan mutu hasil belajar.

Secara umum tingkat variabel kinerja guru dapat dilihat dari Tabel 4 yang menyajikan skor rata-rata dari masing-masing indikator yang dijadikan ukuran kinerja guru

Tabel 2.

Kriteria Gambaran Variabel Kinerja Guru

\begin{tabular}{|c|c|c|c|c|c|c|}
\hline No & Indikator & 4 & 3 & 2 & 1 & Kategori \\
\hline 1 & Mengenal Karakteristik Peserta Didik & $52 \%$ & $45 \%$ & $2 \%$ & $1 \%$ & Tinggi \\
\hline 2 & $\begin{array}{l}\text { Menguasai teori belajar dan prinsip-prinsip } \\
\text { pembelajaran yang mendidik }\end{array}$ & $19 \%$ & $80 \%$ & $1 \%$ & 0 & Tinggi \\
\hline 3 & Pengembangan kurikulum & $20 \%$ & $71 \%$ & $9 \%$ & 0 & Tinggi \\
\hline 4 & $\begin{array}{l}\text { Menguasai Kegiatan Pembelajaran yang } \\
\text { Mendidik }\end{array}$ & $20 \%$ & $74 \%$ & $4 \%$ & $2 \%$ & Tinggi \\
\hline 5 & Memahami dan Mengembangkan Potensi & $33 \%$ & $57 \%$ & $10 \%$ & $1 \%$ & Tinggi \\
\hline 6 & Komunikasi dengan Peserta Didik & $18 \%$ & $75 \%$ & $7 \%$ & 0 & Tinggi \\
\hline 7 & Penilaian dan Evaluasi & $20 \%$ & $66 \%$ & $14 \%$ & 0 & Tinggi \\
\hline 8 & 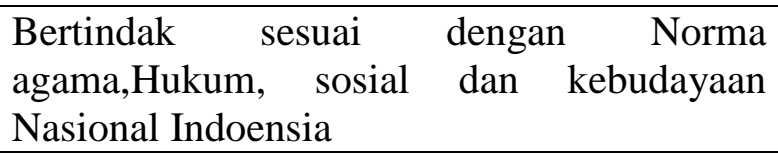 & $22 \%$ & $70 \%$ & $8 \%$ & 0 & Tinggi \\
\hline 9 & $\begin{array}{l}\text { Menunjukkan pribadi yang dewasa dan } \\
\text { teladan }\end{array}$ & $13 \%$ & $73 \%$ & $10 \%$ & $4 \%$ & $\begin{array}{l}\text { Cukup } \\
\text { Tinggi }\end{array}$ \\
\hline 10 & $\begin{array}{l}\text { Etos kerja, tanggungjawab yang tinggi, dan } \\
\text { rasa bangga menjadi guru }\end{array}$ & $19 \%$ & $72 \%$ & $7 \%$ & $2 \%$ & Tinggi \\
\hline 11 & $\begin{array}{l}\text { Bersikap inklusif, bertindak obyektif, serta } \\
\text { tidak diskriminatif }\end{array}$ & $15 \%$ & $75 \%$ & $10 \%$ & 0 & Tinggi \\
\hline 12 & $\begin{array}{l}\text { Komunikasi dengan sesama guru, tenaga } \\
\text { pendidik, orang tua peserta didik, dan } \\
\text { masyarakat }\end{array}$ & $18 \%$ & $65 \%$ & $15 \%$ & $2 \%$ & Tinggi \\
\hline 13 & $\begin{array}{l}\text { Penguasaan materi struktur konsep dan pola } \\
\text { pikir keilmuan yang mendukung mata } \\
\text { pelajaran yang diampu }\end{array}$ & $30 \%$ & $65 \%$ & $5 \%$ & 0 & Tinggi \\
\hline 14 & $\begin{array}{l}\text { Mengembangkan keprofesian } \\
\text { tindakan reflektif }\end{array}$ & $22 \%$ & $59 \%$ & $18 \%$ & $1 \%$ & Tinggi \\
\hline
\end{tabular}

Sumber: Data Terolah

Persentase tertinggi terdapat pada indikator 1 yaitu Mengenal karakteristik peserta didik. Hasil ini menunjukkan bahwa Mengenal karakteristik peserta didik, berada pada kategori tertinggi. Indikator ke 9 yaitu, Menunjukkan pribadi yang dewasa dan teladan mewakili persentase terendah . Hasil ini mengandung makna bahwa menunjukkan pribadi yang dewasa dan teladan guru belum optimal.

\section{Mutu Hasil Belajar}

Instrumen yang dikembangkan pada variabel mutu hasil belajar, dibentuk oleh indikator afektif, kognitif, dan psikomotor. Semua indikator tersebut diarahkan untuk 
mengukur bagaimanakah tingkat mutu hasil belajar siswa SMK Swasta di Kota Bandung. Tabel berikut adalah gambaran tingkat mutu hasil belajar siswa SMK Swasta di Kota Bandung.

Secara umum tingkat mutu hasil belajar siswa SMK Swasta di Kota Bandung, jika dilihat berdasarkan kriteria yang ada pada Tabel 3. Kriteria Gambaran Variabel Mutu hasil belajar, ada pada kategori cukup tinggi. Hasil penelitian tersebut, memberikan informasi bahwa secara keseluruhan, mutu hasil belajar siswa SMK Swasta di Kota Bandung berada pada kategori cukup tinggi. Artinya bahwa Siswa SMK Swasta di Kota Bandung, tingkat mutu hasil belajarnya pada kategori cukup tinggi. Karena ratarata Mutu hasil belajar sebesar 3.11.

Tabel 3.

Gambaran Mutu hasil belajar di SMK Swasta Bandung

\begin{tabular}{|l|l|l|}
\hline Indikator & Rata-rata & Kategori \\
\hline Afektif & 3.27 & Tinggi \\
\hline Kognitif & 2.88 & Cukup Tinggi \\
\hline Psikomotor & 3.15 & Tinggi \\
\hline
\end{tabular}

Sumber: Data terolah

Skor tertinggi berada pada indikator Afektif (Keimanan dan Ketakwaan peserta didik kepada Tuhan YME; Karakter, kejujuran dan kepedulian peserta didik; Tanggungjawab peserta didik; Sifat pembelajar pada peserta didik; Kesehatan Jasmani dan Rohani peserta didik, yang sesuai dengan perkembangan anak). Hasil ini menujukkan afektif siswa , berada pada kategori tinggi. Indikator Kognitif (Pengetahuan factual peserta didik berkenaan dengan ilmu pegetahuan dan teknologi yang dipelajarinya; Pengetahuan konseptual peserta didik berkenaan dengan ilmu pengetahuan dan teknologi yang dipelajarinya; Pengetahuan procedural peserta didik berkenaan dengan ilmu pengetahuan dan teknologi yang dipelajarinya; Pengetahuan metakognitif peserta didik berkenaan dengan ilmu pengetahuan dan teknologi yang diperlajarinya siswa menunjukan skor rata-rata terendah). Hal ini menujukkan bahwa indikator kognitif siswa belum optimal.

\section{PENGUJIAN HIPOTESIS}

Hipotesis yang hendak diuji dalam penelitian ini meliputi: (1) adakah hubungan antara kinerja guru dengan mutu hasil belajar siswa di SMK Swasta Bandung (Studi pada SMK Merdeka, Pasundan 3, dan Bina Sarana Cendikia)?

Berdasarkan dari pengelolahan data diperoleh $t_{\text {hitung }} \geq t_{\text {tabel }}$ dengan nilai $3,214 \geq$ 2,100, yang dimana $\mathrm{H}_{0}$ ditolak dan $\mathrm{H}_{1}$ diterima. Dengan kesimpulan bahwa "kinerja guru SMK Swasta di Bandung (Studi Analisis pada SMK Merdeka, Pasundan 3 dan Bina Sarana Cendikia) dapat meningkatkan mutu hasil belajar siswa. Jadi hipotesis yang tertuang pada kerangka berpikir Bab II yaitu: "Terdapat hubungan yang positif antara kinerja guru dengan mutu hasil belajar di SMK Swasta Bandung (Studi pada SMK Merdeka, Pasundan 3, dan Bina Sarana Cendikia)", dapat diterima dan dapat dibuktikan dengan perhitungan-perhitungan di atas. Artinya bahwa teori-teori yang dijadikan acuan berpikir penulis yang dituangkan dalam kerangka berpikir masih relevan dengan kenyataan di lapangan. 
Hal ini sejalan dengan beberapa penelitian yang berujung kesimpulan adanya pengaruh kinerja guru terhadap mutu hasil belajar. Seperti Studi yang dilakukan Heyneman \& Loxley (1983), Dedi Supriadi (1999), Nana Sudjana (2002).Dalam studi yang dilakukan tersebut dinyatakan bahwa guru lebih dominan menunjang mutu pendidikan (mutu hasil belajar) peserta didik.

\section{KESIMPULAN}

Kinerja Guru pada SMK Swasta di Kota Bandung berada pada kategori Sedang dalam mendukung mutu hasil belajar siswa, yang diukur melalui empat belas indikator, yaitu Mengenal karaktersitik peserta didik, Menguasai teori belajar dan prinsip prinsip pembelajaran yang mendidik, Pengembangan kurikulum, Kegiatan pembelajaran yang mendidik, Memahami dan mengembangkan potensi, Komunikasi dengan peserta didik, Penilaian dan evaluasi, Bertindak sesuai dengan norma agama, hokum, sosial dan kebudayaan nasional Indonesia, Menunjukkan pribadi yang dewasa dan teladan, Etos kerja, tanggungjawab yang tinggi, rasa bangga menjadi guru, Bersikap inklusif, bertindak obyektif, serta tidak diskriminatif, Komunikasi dengan sesame guru, tenaga pendidik, orang tua peserta didik, dan masyarakat, Penguasaan materi struktur konsep dan pola pikir keilmuan yang mendukung mata pelajaran yang diampu, Mengembangkan keprofesian melalui tindakan reflektif. Sementara Mutu hasil belajar siswa SMK Swasta di Kota Bandung berada pada kategori cukup tinggi, yang dikukur melalui 3 indikator yaitu afektif, kognitif dan psikomotor.

Selanjutnya hubungan kinerja guru dengan mutu hasil belajar siswa SMK Swasta di Kota Bandung, berhubungan. Artinya efektif tidak kinerja guru akan diikutin tinggi rendahnya mutu hasil belajar siswa SMK di Kota Bandung dan sebaliknya.

\section{DAFTAR PUSTAKA}

A.A. Anwar Prabu Mangkunegara. (2009). Manajemen Sumber Daya Manusia Perusahaan. Bandung: PT Remaja Rosdayakarya.

Arif Rohman. (2009). Memahami Pendidikan dan Ilmu Pendidikan. Yogyakarta Laksbang Mediatama, Yogyakarta.

Bernardin, H. (2006). Human Resource Management: An Experiental Approach $4^{\text {th }}$ Edition. New York: McGraw Hill Higher Education.

Nana Sudjana. (2002). Dasar-dasar proses belajar mengajar. Bandung: Sinar Baru

Tabrani Rusyan dkk. (2000). Upaya Meningkatkan Budaya Kinerja Guru.Cianjur: CV. Dinamika Karya Cipta.

Tatang, Uep dan Sambas Ali Muhidin, (2011). Desain Penelitian Kuantitatif, Dosen dan Mahasiswa. Bandung: Karya Adhika Utama

Tatang, Uep dan Sambas Ali Muhidin, (2007). Permendiknas No. 17 Tahun 2007 Tentang Kualifikasi Akademik dan Kompetensi Guru. Bandung 